\title{
Dexmedetomidine suppresses interleukin-1 $\beta$-induced interleukin-6 synthesis in rat glial cells
}

\author{
KUMIKO TANABE $^{1}$, RIE MATSUSHIMA-NISHIWAKI ${ }^{2}$, OSAMU KOZAWA $^{2}$ and HIROKI IIDA ${ }^{1}$ \\ Departments of ${ }^{1}$ Anesthesiology and Pain Medicine, and ${ }^{2}$ Pharmacology, \\ Gifu University Graduate School of Medicine, Gifu 501-1194, Japan
}

Received March 5, 2014; Accepted July 18, 2014

DOI: $10.3892 /$ ijmm.2014.1863

\begin{abstract}
Dexmedetomidine, an $\alpha_{2}$-adrenoceptor agonist, is used as a sedative medication for criticalyl ill patients and is known to exert neuroprotective effects by direct action on neurons and indirect action on neurons through astrocytes. Interleukin (IL)-6 plays a key role in neuroinflammation, which accompanies infection, traumatic brain injury, ischemia, neurodegenerative disorders, as both a pro-inflammatory cytokine and an anti-inflammatory cytokine. Dexmedetomidine suppresses immune function. However, the effects of dexmedetomidine on cytokine synthesis in the central nervous system (CNS) remain elusive. We previously reported that IL-1 $\beta$ stimulates IL-6 synthesis in the rat C6 glioma cell line through the phosphorylation of $\mathrm{p} 38$ mitogen-activated protein (MAP) kinase, stress-activated protein kinase (SAPK)/c-Jun $\mathrm{N}$-terminal kinase $(\mathrm{JNK})$ and $\mathrm{I} \kappa \mathrm{B}$. In the present study, we investigated the effects of dexmedetomidine on the IL-1 $\beta$ induced IL-6 synthesis in C6 cells. Dexmedetomidine inhibited the IL-1 $\beta$-stimulated IL- 6 release and mRNA expression in C6 cells. 8-Bromo-adenosine-3',5'-cyclic monophosphate, but not 8-bromo-guanosine 3',5'-cyclic monophosphate, significantly enhanced the IL- $1 \beta$-induced IL- 6 release and mRNA expression. However, dexmedetomidine failed to affect cAMP accumulation in the cells treated with IL-1 $\beta$ or forskolin, an activator of adenylyl cyclase. Yohimbine, an $\alpha_{2}$-adrenoceptor antagonist, did not reverse the suppressive effects of dexmedetomidine on the IL-1 $\beta$-induced IL- 6 release. Dexmedetomidine did not affect the IL-1 $\beta$-induced phosphorylation of p38 MAP

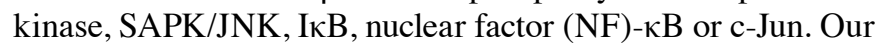
findings strongly suggest that dexmedetomidine inhibits the IL-1 $\beta$-induced IL- 6 synthesis independently of the adenylyl cyclase-cAMP pathway through $\alpha_{2}$-adrenoceptors in C6 glioma cells. It is possible that dexmedetomidine may affect
\end{abstract}

Correspondence to: $\mathrm{Dr}$ Kumiko Tanabe, Department of Anesthesiology and Pain Medicine, Gifu University Graduate School of Medicine, Yanagido 1-1, Gifu 501-1194, Japan

E-mail:kumiko-t@m2.gyao.ne.jp

Key words: $\alpha_{2}$-adrenoceptor, dexmedetomidine, interleukin-1 $\beta$, interleukin-6, intracellular signaling the immune system in the CNS by regulating the production of IL-6.

\section{Introduction}

Dexmedetomidine, which is known as a potent $\alpha_{2}$-adrenoceptor agonist, induces analgesia, anxiolysis, sedation and sympatholysis (1). The neuroprotective effects of dexmedetomidine have been shown in transient cerebral ischemia models $(1,2)$. Dexmedetomidine directly affects neurons and exerts protective effects through the attenuation of catecholamine and glutamate levels or the prevention of neuronal apoptosis (1-3). Astrocytes regulate neurons by releasing neurotransmitters and other extracellular signaling molecules and exert neuroprotective effects through the uptake of synaptic glutamate and the production of glutathione (4). Dexmedetomidine also affects astrocytes $(1,2)$. Dexmedetomidine protects neurons by increasing glutamate uptake by astrocytes in hippocampal slices exposed to hypoxia (5), promoting the release of glial cell line-derived neurotrophic factor (GDNF) from rat cultured astrocytes following oxygen-glucose deprivation (6), and upregulating the release of hypoxia-inducible factor (HIF)-1 $\alpha$ and vascular endothelial growth factor (VEGF) from rat C6 glioma cells following oxygen-glucose deprivation (7). However, the effects of dexmedetomidine and the exact mechanisms involving astrocytes have not yet been fully elucidated.

In the central nervous system (CNS) of healthy individuals, interleukin (IL)-1 $\beta$, a pro-inflammatory cytokine, is expressed at low levels (8). IL-1 plays an important role in some physiological functions, including sleep and synaptic plasticity (8). The levels of IL-1 $\beta$ are increased in cerebrospinal fluid in patients following traumatic brain injury, stroke and neurodegenerative diseases $(8,9)$. The main source of brain IL-1 $\beta$ is microglia following acute insults $(8,9)$. Astrocytes also produce IL-1 $\beta$ at a later stage than microglia $(8,9)$. IL-1 $\beta$ induces the production of other cytokines, such as tumor necrosis factor (TNF)- $\alpha$ and IL-6, from microglia and astrocytes (8). Cytokines have been implicated not only in neuroinflammation, but also in astrogliosis, brain ischemia and chronic diseases of the CNS $(8,10)$. Dexmedetomidine suppresses systemic immune function similar to other sedative medications (11). Dexmedetomidine decreases transient global cerebral ischemia-induced neuronal apoptosis and plasma TNF- $\alpha$ levels (12), suppresses plasma IL-6 levels in septic rats (13), decreases serum IL-6 levels 
compared with propofol administration in post-operative patients (14) and decreases serum TNF- $\alpha$, IL-1 $\beta$ or IL-6 levels compared with midazolam administration in patients with sepsis (15). C6 cells, a rat glioma cell line, have frequently been used for the investigation of the mechanisms of IL-6 production or release (16-18). We previously reported that midazolam, a sedative agent used in intensive care units, inhibits the IL-1 $\beta$ induced IL-6 release from C6 cells (17). However, the effects of dexmedetomidine on cytokine synthesis in brain cells have not yet been fully elucidated. In the present study, we investigated the effects and mechanism of action of dexmedetomidine on the IL-1 $\beta$-induced release of IL- 6 from glial cells.

\section{Materials and methods}

Materials. Dexmedetomidine was kindly provided by Orion Pharma (Turku, Finland). 8-Bromo-adenosine-3',5'cyclic monophosphate (8-bromo-cAMP), forskolin or 12-O-tetradecanoylphorbol-13-acetate (TPA) were purchased from Sigma Chemical Co. (St. Louis, MO, USA). 8-Bromoguanosine 3',5'-cyclic monophosphate (8-bromo-cGMP) was purchased from Calbiochem-Novabiochem Co. (La Jolla, CA, USA). Yohimbine hydrochloride (yohimbine) was purchased from Wako Pure Chemical Industries (Osaka, Japan). IL-6 enzyme-linked immunosorbent assay (ELISA) kit and IL-1 $\beta$ were obtained from R\&D Systems (Minneapolis, MN, USA). The cAMP ELISA kit was purchased from Enzo Life Sciences Inc. (Farmingdale, NY, USA). $\alpha_{2 \mathrm{~A}}$-adrenoceptor antibody was purchased from Santa Cruz Biotechnology (Santa Cruz, CA, USA). Phospho-specific p38 mitogen-activated protein (MAP) kinase, p38 MAP kinase, phospho-specific stress-activated protein kinase/c-Jun N-terminal kinase (SAPK/ JNK), SAPK/JNK, phospho-c-Jun, c-Jun, phospho-specific I $\mathrm{B}$, $\mathrm{I} \kappa \mathrm{B}$, phospho-nuclear factor $(\mathrm{NF})-\kappa \mathrm{B}$ (serine 536 ) or $\mathrm{NF}-\kappa \mathrm{B}$ antibodies were purchased from Cell Signaling Technology (Beverly, MA, USA). An enhanced chemiluminescence western blotting detection system was obtained from GE Healthcare Ltd. (Buckinghamshire, UK). Other materials and chemicals were obtained from commercial sources. Forskolin, TPA and yohimbine were dissolved in dimethyl sulfoxide (DMSO), and others were dissolved in assay buffer (5 mM HEPES, pH7.4, $150 \mathrm{mM}$ $\mathrm{NaCl}, 5 \mathrm{mM} \mathrm{KCl}, 5.5 \mathrm{mM}$ glucose, $0.8 \mathrm{mM} \mathrm{MgSO}_{4}, 1 \mathrm{mM}$ $\mathrm{CaCl}_{2}$, containing $0.01 \%$ albumin) as the vehicle. The maximum concentration of DMSO was $0.1 \%$, which did not affect the assay for IL-6 or cAMP.

Cell culture. Rat C6 glioma cells, obtained from the American Type Culture Collection (ATCC; Rockville, MD, USA), were seeded into $35-\mathrm{mm}\left(5 \times 10^{4}\right.$ cells/dish $)$ or $90-\mathrm{mm}\left(2 \times 10^{5}\right.$ cells/ dish) diameter dishes and maintained in Dulbecco's modified Eagle's medium (DMEM) containing 10\% fetal bovine serum (FBS) at $37^{\circ} \mathrm{C}$ in a humidified atmosphere of $5 \% \mathrm{CO}_{2} / 95 \%$ air. The medium was exchanged for serum-free DMEM after 6 days. The cells were then used for the experiments after $24 \mathrm{~h}$. The cells were pre-treated with dexmedetomidine, forskolin, 8-brom-cAMP, 8-bromo-cGMP, TPA or yohimbine for $60 \mathrm{~min}$ where indicated.

Assay for IL-6. Cultured cells (35-mm diameter dishes) were stimulated with $10 \mathrm{ng} / \mathrm{ml}$ IL-1 $\beta$ in serum-free DMEM for
$36 \mathrm{~h}$. The conditioned medium was collected at the end of the incubation period and the IL-6 concentration was measured using an ELISA kit. The absorbance of each sample at 450 and $540 \mathrm{~nm}$, respectively, was measured with a Multiscan JX ELISA reader (Thermo Labsystems, Helsinki, Finland). Absorbance was corrected with reference to a standard curve.

Assay for cAMP. Cultured cells (35-mm diameter dishes) were pre-incubated with $0.5 \mathrm{mM}$ 3-isobutyl-1-methylxanthine, a cyclic nucleotide phosphodiesterase inhibitor, for $20 \mathrm{~min}$ for the inhibition of cAMP decomposition, and then stimulated with $10 \mathrm{ng} / \mathrm{ml} \mathrm{IL}-1 \beta$ or $10 \mu \mathrm{M}$ forskolin for $20 \mathrm{~min}$. The reaction was terminated by aspiration of the assay buffer. Intracellular cAMP was extracted with $0.1 \mathrm{M} \mathrm{HCl}$. The extracted cAMP was measured using an ELISA kit. The absorbance of each sample at $405 \mathrm{~nm}$ was measured using a Multiscan JX ELISA reader. Absorbance was corrected with reference to a standard curve.

Real-time reverse transcription $(R T)$-polymerase chain reaction $(P C R)$. Cultured cells (35-mm diameter dishes) were stimulated with $10 \mathrm{ng} / \mathrm{ml} \mathrm{IL-1 \beta}$ for $6 \mathrm{~h}$. Total RNA was isolated and transcribed into cDNA using TRIzol reagent and the Omniscript Reverse Transcriptase kit (QIAGEN, Hilden, Germany). Real-time RT-PCR was performed using a LightCycler system (Roche Diagnostics, Basel, Switzerland) in capillaries and FastStart DNA Master SYBR-Green I provided with the kit. Sense and antisense primers for mouse IL-6 mRNA or rat GAPDH mRNA were purchased from Takara Bio Inc. (Tokyo, Japan) (primer set ID: MA039013 or RA015380, respectively). The amplified products were determined by melting curve analysis and agarose electrophoresis. The IL-6 mRNA levels were normalized to those of GAPDH mRNA.

Western blot analysis. Cultured cells (90-mm diameter dishes) were stimulated with $10 \mathrm{ng} / \mathrm{ml}$ IL-1 $\beta$ in serum-free DMEM for the indicated periods of time. The cells were washed twice with phosphate-buffered saline and then lysed and sonicated in a lysis buffer containing $62.5 \mathrm{mM}$ Tris- $\mathrm{HCl}$ (pH 6.8), 2\% sodium dodecyl sulfate (SDS), $50 \mathrm{mM}$ dithiothreitol and $10 \%$ glycerol. The sample was used for the analysis by western blotting as previously described (17). SDS-polyacrylamide gel electrophoresis (PAGE) was performed according to the method of Laemmli (19) in $10 \%$ polyacrylamide gels. Western blot analysis was performed using antibodies against $\alpha_{2 \mathrm{~A}}$-adrenoceptor, phospho-specific p38 MAP kinase, p38 MAP kinase, phospho-specific SAPK/JNK, SAPK/JNK,

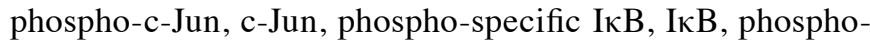
$\mathrm{NF}-\kappa \mathrm{B}$ or $\mathrm{NF}-\kappa \mathrm{B}$ with peroxidase-labeled antibodies raised in goat against rabbit IgG being used as secondary antibodies. The peroxidase activity on polyvinylidene difluoride membranes was visualized on X-ray film by means of an enhanced chemiluminescence western blotting detection system.

Statistical analysis. The data were analyzed by ANOVA followed by Bonferroni's method for multiple comparisons between pairs. A value of $\mathrm{P}<0.05$ was considered to indicate a statistically significant difference. All data are presented as the means \pm SD of triplicate determinations. Each experiment was repeated 3 times with similar results. 


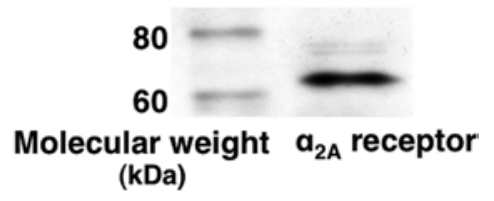

Figure 1. Expression of $\alpha_{2 A}$-adrenoceptors in C6 cells. The extracts of unstimulated cultured cells were subjected to SDS-PAGE with subsequent western blot analysis with antibody against $\alpha_{2 \mathrm{~A}}$-adrenoceptors. Similar results were obtained with 2 additional and different cell preparations.
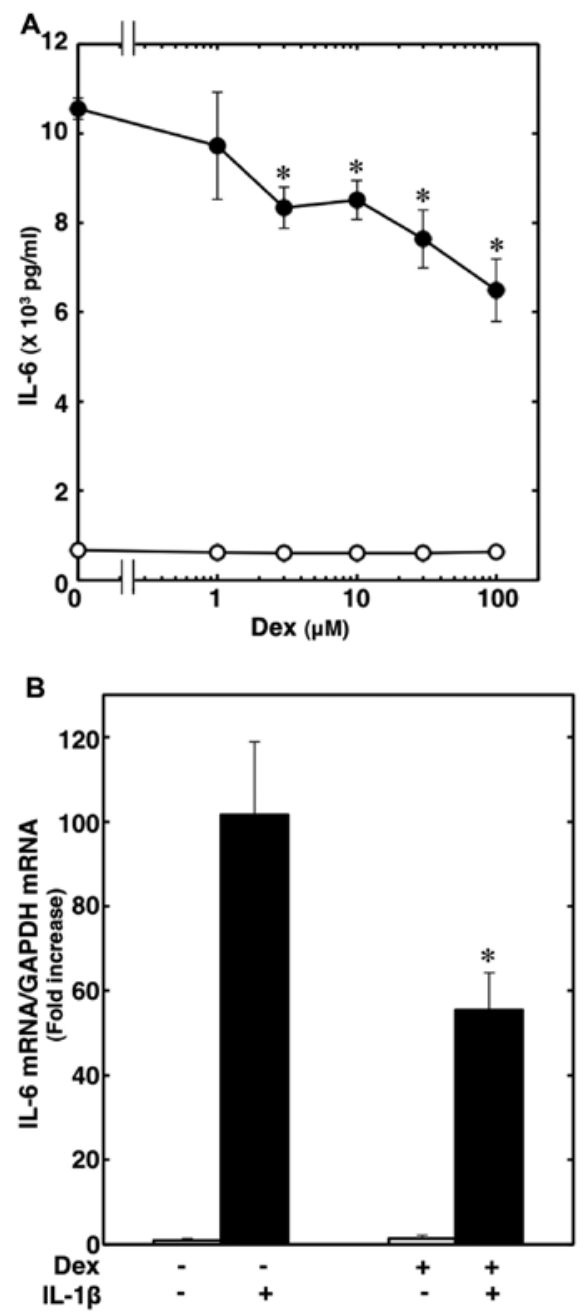

Figure 2. (A) Effect of dexmedetomidine (Dex) on the IL-1 $\beta$-induced release of IL-6. Cultured cells were pre-treated with various concentrations of Dex for $60 \mathrm{~min}$, and then stimulated with $10 \mathrm{ng} / \mathrm{ml} \mathrm{IL}-1 \beta$ (closed circle) or the vehicle (open circle) for $36 \mathrm{~h}$. (B) Effects of Dex on the IL-1 $\beta$-induced IL-6 mRNA expression. Cultured cells were pre-treated with $30 \mu \mathrm{M}$ Dex or the vehicle, and then stimulated with $10 \mathrm{ng} / \mathrm{ml} \mathrm{IL-1} \beta$ or the vehicle for $6 \mathrm{~h}$. Total RNA was isolated and transcribed into cDNA. The expression of IL-6 mRNA and GAPDH mRNA was quantified by real-time RT-PCR. IL-6 mRNA levels were normalized to those of GAPDH mRNA. Results were standardized for the value of unstimulated cells. Each value represents the means \pm SD of triplicate independent determinations of a representative experiment carried out 3 times. Similar results were obtained with 2 additional and different cell preparations. ${ }^{*} \mathrm{P}<0.05$, in comparison to the value obtained with IL-1 $\beta$ treatment alone.

\section{Results}

Effects of dexmedetomidine on the IL-1 $\beta$-induced IL-6 release and IL- 6 mRNA expression in C6 cells. It has been
Table I. Effects of dexmedetomidine on cAMP accumulation in $\mathrm{C} 6$ cells following treatment with IL-1 $\beta$.

\begin{tabular}{lcc}
\hline $\begin{array}{l}\text { Dexmedetomidine } \\
(50 \mu \mathrm{M})\end{array}$ & $\begin{array}{c}\mathrm{IL}-1 \beta \\
(10 \mathrm{ng} / \mathrm{ml})\end{array}$ & $\begin{array}{c}\mathrm{cAMP} \\
(\mathrm{pmol} / \mathrm{ml})\end{array}$ \\
\hline- & - & $8.7 \pm 0.8$ \\
- & + & $8.0 \pm 1.4$ \\
+ & - & $6.1 \pm 3.4$ \\
+ & + & $9.8 \pm 0.3$
\end{tabular}

Cultured cells were pre-incubated with $0.5 \mathrm{mM}$ 3-isobutyl-1-methylxanthine for $20 \mathrm{~min}$, and then pre-treated with $50 \mu \mathrm{M}$ dexmedetomidine or the vehicle for $60 \mathrm{~min}$. The cells were stimulated with $10 \mathrm{ng} / \mathrm{ml}$ interleukin (IL)-1 $\beta$ for $20 \mathrm{~min}$. Each value represents the means $\pm \mathrm{SD}$ of triplicate independent determinations of a representative experiment carried out 3 times. Similar results were obtained with 2 additional and different cell preparations.

reported that there are $\alpha_{2 \mathrm{~A}}$-adrenoceptors, but not $\alpha_{2 \mathrm{~B}^{-}}$and $\alpha_{2 \mathrm{C}}$-adrenoceptors, in C6 glioma cells (20). We confirmed the expression of $\alpha_{2 \mathrm{~A}}$-adrenoceptors in these cells (Fig. 1). Subsequently, we investigated effects of dexmedetomidine on the IL-1 $\beta$-induced release of IL-6. It has been reported that IL-1 $\beta$ induces IL-6 mRNA expression and IL-6 release from C6 glioma cells (16). Dexmedetomidine, which on its own had little effect on the IL-6 levels, significantly suppressed the IL-1 $\beta$-induced IL- 6 release. The inhibitory effects of dexmedtomidine were concentration-dependent between 1 and $100 \mu \mathrm{M}$ (Fig. 2A). Dexmedetomidine (100 $\mu \mathrm{M})$ suppressed the effects of IL- $1 \beta$ by approximately $40 \%$. The viability of the cells treated with $100 \mu \mathrm{M}$ dexmedetomidine and $10 \mathrm{ng} / \mathrm{ml} \mathrm{IL-1 \beta}$ for $36 \mathrm{~h}$ was $>97 \%$ compared to the cells without treatment, as shown by trypan blue staining (data not shown). Moreover, dexmedetomidine $(30 \mu \mathrm{M})$ markedly suppressed the IL-1 $\beta$ induced IL-6 mRNA expression, and caused approximately a $50 \%$ inhibition of the effect of IL-1 $\beta$ (Fig. 2B).

Effects of 8-bromo-cAMP on the IL-1 $\beta$-induced IL-6 release and IL-6 mRNA expression in C6 cells. Dexmedetomidine inhibits the adenylyl cyclase activity through the pertussis toxinsensitive GTP-binding protein $\left(\mathrm{G}_{\mathrm{i} / \mathrm{o}}\right)$ coupling with its receptors, $\alpha_{2}$-adrenoceptors $(1,21)$. Adenylyl cyclase produces cAMP from adenosine triphosphate (ATP) $(1,21)$. We investigated whether the activation of the adenylyl cyclase-cAMP pathway is involved in the IL-1 $\beta$-induced release of IL-6 from C6 cells. IL-1 $\beta$ on its own did not affect the accumulation of cAMP in the C6 cells (Table I). It has been reported that forskolin, a direct activator of adenylyl cyclase, or dibutyryl cAMP, a permeable analogue of cAMP, significantly enhances the IL-1 $\beta$-induced release of IL-6 from C6 cells (18). We found that 8-bromo-cAMP, another plasma membrane-permeable cAMP analogue, which alone slightly increased the release of IL-6, significantly enhanced the IL-1 $\beta$-induced release of IL-6 (Fig. 3A). The amplifying effects of 8-bromo cAMP were concentration-dependent between 0.1 and $2 \mathrm{mM}$ (Fig. 3A). 8-Bromo cAMP (1 mM) markedly enhanced the IL-1 $\beta$-induced IL-6 mRNA expression (Fig. 3B). In addition, $\alpha_{2}$-adrenoceptor agonists have been shown to 

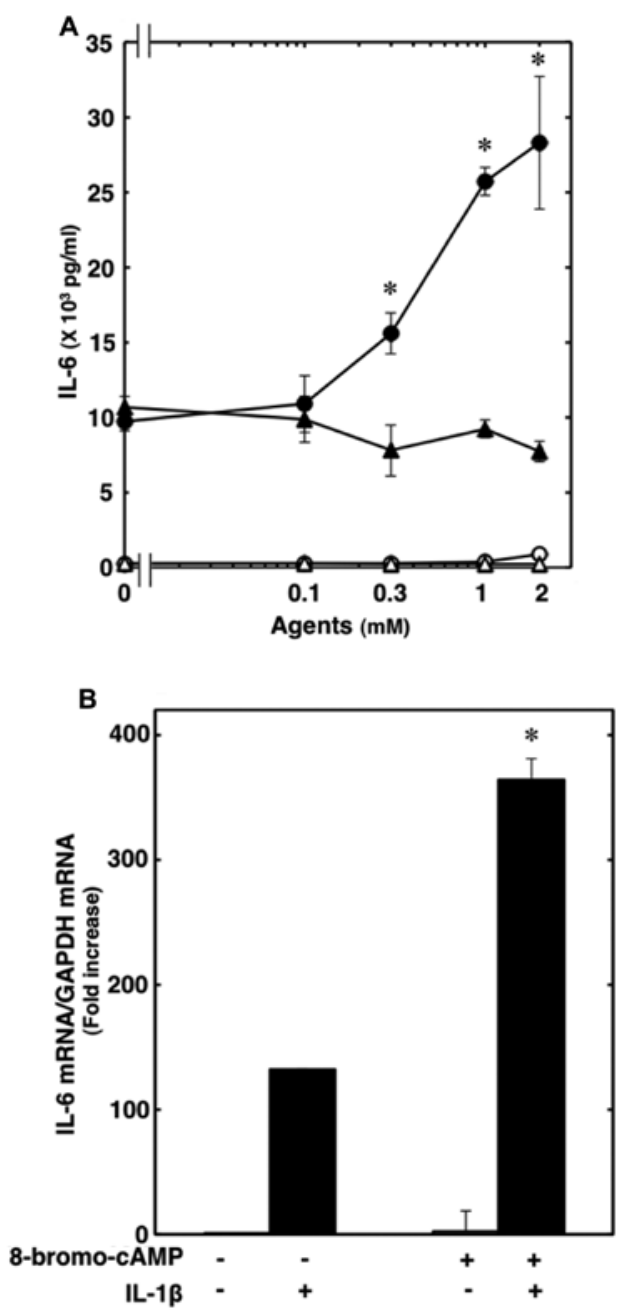

Figure 3. (A) Effects of 8-bromo-cAMP or 8-bromo-cGMP on the IL-1 $\beta$-induced IL-6 release. Cultured cells were pre-treated with various concentrations of 8-bromo-cAMP (circle) or 8-bromo-cGMP (triangle) for $60 \mathrm{~min}$, and then

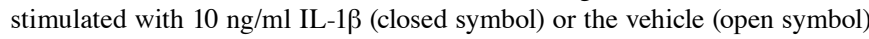
for $36 \mathrm{~h}$. (B) Effects of 8-bromo-cAMP on the IL-1 $\beta$-induced IL-6 mRNA expression. Cultured cells were pre-treated with $1 \mathrm{mM} 8$-bromo-cAMP or the vehicle, and then stimulated with $10 \mathrm{ng} / \mathrm{ml} \mathrm{IL-1 \beta}$ or the vehicle for $6 \mathrm{~h}$. Total RNA was isolated and transcribed into cDNA. The expression of IL-6 mRNA and GAPDH mRNA was quantified by real-time RT-PCR. IL-6 mRNA levels were normalized to those of GAPDH mRNA. Results were standardized for the value of unstimulated cells. Each value represents the means \pm SD of triplicate independent determinations of a representative experiment carried out 3 times. Similar results were obtained with 2 additional and different cell preparations. ${ }^{*} \mathrm{P}<0.05$, in comparison to the value obtained with IL-1 $\beta$ treatment alone.

decrease cerebellar cGMP levels (18). We investigated whether cGMP affects the IL-1 $\beta$-induced IL-6 release from C6 cells. However, 8-bromo-cGMP failed to affect the IL-1 $\beta$-induced release of IL-6 at up to $2 \mathrm{mM}$ (Fig. 3A).

Effect of dexmedetomidine on the forskolin-induced cAMP accumulation in C6 cells. We then investigated the association between dexmedetomidine and the adenylyl cyclase-cAMP pathway in the IL-1 $\beta$-stimulated IL- 6 synthesis in C6 cells. Dexmedetomidine $(50 \mu \mathrm{M})$ had little effect on cAMP accumulation regardless of the presence of IL-1 $\beta$ (Table I). Additionally, we confirmed that forskolin increased cAMP accumulation in the C6 cells (Table II). However, dexmedetomidine (50 $\mu \mathrm{M})$
Table II. Effects of dexmedetomidine on the forskolin-induced cAMP accumulation in C6 cells.

\begin{tabular}{lcc}
\hline $\begin{array}{l}\text { Dexmedetomidine } \\
(50 \mu \mathrm{M})\end{array}$ & $\begin{array}{c}\text { Forskolin } \\
(10 \mu \mathrm{M})\end{array}$ & $\begin{array}{c}\text { cAMP } \\
(\mathrm{pmol} / \mathrm{ml})\end{array}$ \\
\hline- & - & $13.4 \pm 2.9$ \\
- & + & $814.9 \pm 50.4^{\mathrm{a}}$ \\
+ & - & $16.8 \pm 5.6$ \\
+ & + & $787.7 \pm 22.3$ \\
\hline
\end{tabular}

Cultured cells were pre-incubated with $0.5 \mathrm{mM} 3$-isobutyl-1-methylxanthine for $20 \mathrm{~min}$, and then pre-treated with $50 \mu \mathrm{M}$ dexmedetomidine or the vehicle for $60 \mathrm{~min}$. The cells were stimulated with $10 \mu \mathrm{M}$ forskolin for $20 \mathrm{~min}$. Each value represents the means \pm SD of triplicate independent determinations of a representative experiment carried out 3 times. Similar results were obtained with 2 additional and different cell preparations. ${ }^{\mathrm{a}} \mathrm{P}<0.05$, in comparison to the value obtained from unstimulated cells.

did not affect the forskolin-induced cAMP accumulation (Table II). Therefore, it seems likely that the suppression of the IL-1 $\beta$-stimulated IL- 6 release by dexmedetomidine is not due to the suppression of the adenylyl cyclase-cAMP pathway.

Effect of yohimbine on the suppression of IL-1 $\beta$-induced IL-6 release from $C 6$ cells by dexmedetomidine. Subsequently, we investigated whether the suppressive effects of dexmedetomidine are mediated through $\alpha_{2}$-adrenoceptors. Yohimbine (10 $\mu \mathrm{M})$, an $\alpha_{2}$-adrenoceptor antagonist, did not reverse the suppressive effects of dexmedetomidine on the IL-1 $\beta$-induced IL-6 release (Fig. 4). Therefore, it seems unlikely that dexmedetomidine suppresses the IL-1 $\beta$-induced release of IL-6 through $\alpha_{2}$-adrenoceptors.

Effect of TPA on the IL-1 $\beta$-induced IL-6 release from C6 cells. It has been reported that $\alpha_{2}$-adrenoceptor agonists also bind to imidazoline receptors, which activate phospholipase $\mathrm{C}$ and protein kinase $C(1,2,22)$. Finally, we investigated the association between the activation of protein kinase $\mathrm{C}$ and the IL-1 $\beta$-induced release of IL-6 from C6 cells. TPA, a specific protein kinase $\mathrm{C}$ activator (23), significantly enhanced the release of IL- 6 and markedly enhanced the IL-1 $\beta$-induced release of IL-6 (Fig. 5).

Effects of dexmedetomidine on the IL-1 $\beta$-induced phosphorylation of 38 MAP kinase, SAPK/JNK, c-Jun, I $\kappa B$ and $N F-\kappa B$ or the levels of $I \kappa B$ in $C 6$ cells. We have previously reported that IL- $1 \beta$ stimulates IL-6 synthesis through p38 MAP kinase, SAPK/JNK or the I $\kappa \mathrm{B} / \mathrm{NF}-\kappa \mathrm{B}$ pathway in C6 cells (17). In order to elucidate the mechanisms through which dexmedetomidine alters IL-1 $\beta$ intracellular signaling, we examined the effects of dexmedetomidine on the IL- $1 \beta$-induced phosphorylation of p38 MAP kinase, SAPK/JNK, c-Jun, IкB and $\mathrm{NF}-\kappa \mathrm{B}$ or the I $\kappa \mathrm{B}$ levels. Dexmedetomidine $(100 \mu \mathrm{M}) \mathrm{did}$ not affect the IL-1 $\beta$-induced phosphorylation of p38 MAP kinase,

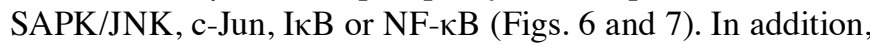
dexmedetomidine failed to affect the levels of I $\mathrm{B}$ (Fig. 7). 


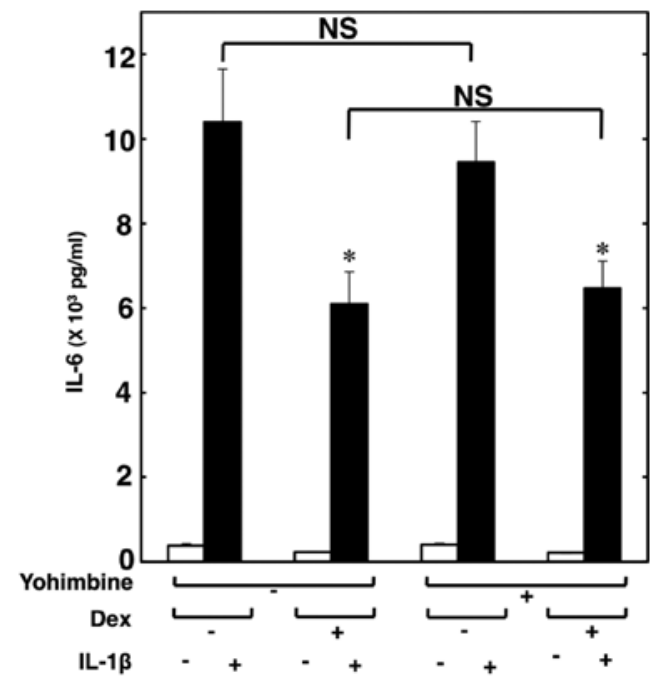

Figure 4. Effects of yohimbine on the suppression of IL-1 $\beta$-induced IL-6 release by dexmedetomidine (Dex). Cultured cells were pre-treated with $10 \mu \mathrm{M}$ yohimbine or the vehicle for $60 \mathrm{~min}$, and then pre-incubated with $50 \mu \mathrm{M}$ Dex or the vehicle for $60 \mathrm{~min}$. The cells were stimulated with $10 \mathrm{ng} / \mathrm{ml} \mathrm{IL}-1 \beta$ or the vehicle for $36 \mathrm{~h}$. Each value represents the means \pm SD of triplicate independent determinations of a representative experiment carried out 3 times. Similar results were obtained with 2 additional and different cell preparations. ${ }^{*} \mathrm{P}<0.05$, in comparison to the value obtained with IL- $1 \beta$ treatment alone.

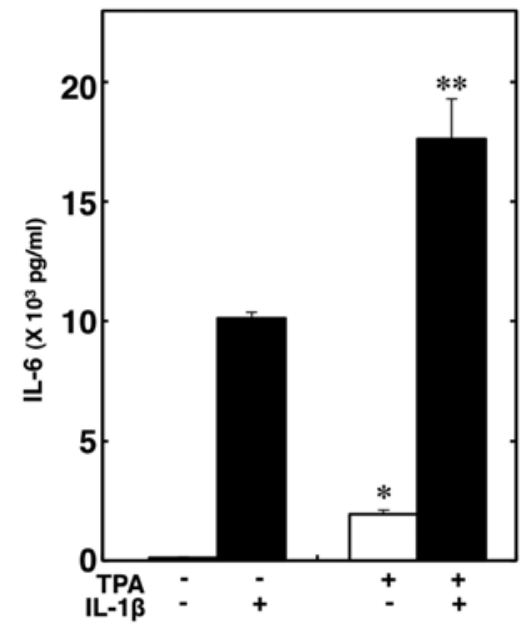

Figure 5. Effects of 12-O-tetradecanoylphorbol-13-acetate (TPA) on the IL-1 $\beta$-induced release of IL- 6 . Cultured cells were pre-treated with $10 \mathrm{nM}$ TPA or the vehicle for $60 \mathrm{~min}$, and then stimulated with $10 \mathrm{ng} / \mathrm{ml} \mathrm{IL}-1 \beta$ or the vehicle for $36 \mathrm{~h}$. Each value represents the means \pm SD of triplicate independent determinations of a representative experiment carried out 3 times. Similar results were obtained with 2 additional and different cell preparations. ${ }^{*} \mathrm{P}<0.05$, in comparison to the value obtained from unstimulated cells. ${ }^{* *} \mathrm{P}<0.05$, in comparison to the value obtained with IL-1 $\beta$ treatment alone.

\section{Discussion}

In this study, we first confirmed the expression of $\alpha_{2 \mathrm{~A}}$-adrenoceptors in C6 cells. Thereafter, we showed that dexmedetomidine significantly suppressed the IL-1 $\beta$-induced IL-6 synthesis in C6 glioma cells. Dexmedetomidine, a specific agonist of $\alpha_{2}$-adrenoceptor, binds to $\alpha_{2}$-adrenoceptors, [all 3 subtype receptors $\left(\alpha_{2 \mathrm{~A} / \mathrm{D}}, \alpha_{2 \mathrm{~B}}\right.$ and $\left.\alpha_{2 \mathrm{C}}\right)$ ], which are coupled to pertussis toxin-sensitive $\mathrm{G}_{\mathrm{i} / \mathrm{o}}$ protein $(2,21)$. Pertussis toxin-

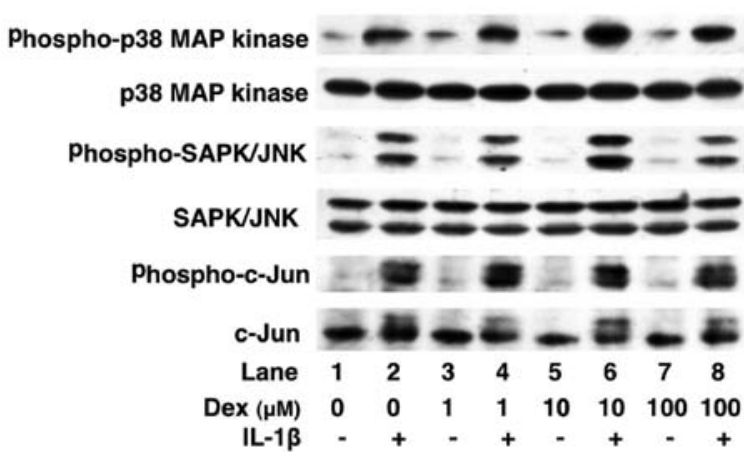

Figure 6. Effects of dexmedetomidine (Dex) on the IL-1 $\beta$-induced phosphorylation of p38 MAP kinase, SAPK/JNK or c-Jun in C6 cells. Cultured cells were pre-treated with various concentrations of Dex for $60 \mathrm{~min}$, and then stimulated with $10 \mathrm{ng} / \mathrm{ml} \mathrm{IL-1 \beta}$ or the vehicle for $20 \mathrm{~min}$. The extracts of cells were subjected to SDS-PAGE with subsequent western blot analysis with antibodies against phospho-specific p38 MAP kinase, p38 MAP kinase, phospho-specific SAPK/JNK, SAPK/JNK, phospho-c-Jun or c-Jun. Similar results were obtained with 2 additional and different cell preparations.

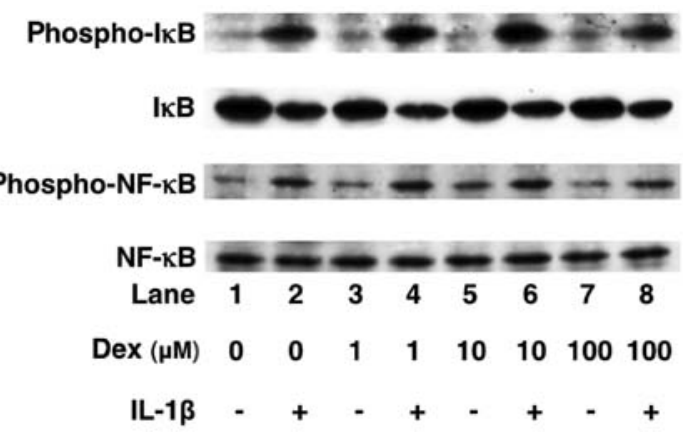

Figure 7. Effects of dexmedetomidine (Dex) on the IL-1 $\beta$-induced phosphorylation of $\mathrm{I} \kappa \mathrm{B}$ or NF- $\kappa \mathrm{B}$ in $\mathrm{C} 6$ cells. Cultured cells were pre-treated with various concentrations of Dex for $60 \mathrm{~min}$, and then stimulated with $10 \mathrm{ng} /$ $\mathrm{ml} \mathrm{IL}-1 \beta$ or the vehicle for $30 \mathrm{~min}$. The extracts of cells were subjected to SDS-PAGE with subsequent western blot analysis with antibodies against

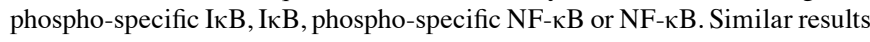
were obtained with 2 additional and different cell preparations.

sensitive $G_{i / o}$ protein suppresses adenylyl cyclase activity, which produces cAMP from ATP (2). In the present study, IL-1 $\beta$ by itself did not increase cAMP accumulation in C6 cells. It has been reported that the activation of adenylyl cyclase-cAMP pathway enhances the IL-1 $\beta$-induced IL-6 release from C6 cells (18). We found that 8-bromo-cAMP enhanced the IL-1 $\beta$-induced IL- 6 mRNA levels and release in these cells, whereas 8-bromo-cGMP did not affect the IL-6 release. Based on these findings, it is possible that the adenylyl cyclase-cAMP pathway, but not the guanylyl cyclasecGMP system, enhances the IL- $1 \beta$-induced IL- 6 release and its mRNA expression in C6 cells. Therefore, we investigated whether the adenylyl cyclase-cAMP system is involved in suppressive effect of dexmedetomidine on IL-6 synthesis in C6 cells. We showed that dexmedetomidine had little effect on the cAMP levels in the presence or absence of IL-1 $\beta$. Forskolin is known as a direct activator of adenylyl cyclase (24) and increases cAMP accumulation in C6 cells (25). It is well known that $\alpha_{2}$-adrenoceptor agonists suppress adenylyl cyclase activity $(1,2,21)$. However, we found that dexmedetomidine 
failed to affect the accumulation of cAMP in the cells treated with IL-1 $\beta$ or forskolin. Yohimbine, an $\alpha_{2}$-adrenoceptor antagonist, did not reverse the suppressive effects of dexmedetomidne. It seems unlikely that dexmedetomidine suppresses the IL-1 $\beta$-induced release of IL- 6 through $\alpha_{2}$-adrenoceptors. In addition to $\alpha_{2}$-adrenoceptors, dexmedetomidine contains an imidazol ring, which can bind imidazoline receptors $(1,2)$. Imidazoline receptors are coupled to the activation of phospholipase $\mathrm{C}$ and protein kinase $\mathrm{C}$ (22). However, we found that TPA, a direct activator of protein kinase C (23), markedly enhanced the IL-1 $\beta$-induced relesae of IL- 6 and that bisindolylmaleimide $\mathrm{I}$, a protein kinase $\mathrm{C}$ inhibitor, did not reverse the suppression of IL- 6 release by dexmedetomidine in C6 cells (data not shown). Based on our findings, it seems unlikely that dexmedetomidine suppresses the IL-1 $\beta$-induced IL-6 release through $\alpha_{2}$-adrenoceptors, imidazoline receptors or the cGMP pathway in C6 glioma cells. We previously reported that IL-1 $\beta$ stimulates IL-6 synthesis through p38 MAP kinase signaling, SAPK/JNK signaling and $\mathrm{I} \kappa \mathrm{B} / \mathrm{NF}-\kappa \mathrm{B}$ signaling in C6 cells (17). SAPK/JNK activates the transcription factor, c-Jun, by phosphorylation (26). The heterodimer complex of c-Jun and c-Fos is known as activator protein-1 (AP-1) (26). On the other hand, I $\mathrm{B}$ is phosphorylated and degradated, and subsequently, $\mathrm{NF}-\kappa \mathrm{B}$ is freed from $\mathrm{I} \kappa \mathrm{B}$ and translocates to the nucleus (26). Transcription factors, such as AP-1 and NF- $\kappa \mathrm{B}$, bind to DNA-regulatory sequences to modulate the rate of gene transcription (26). In the present study, dexmedetomidine did not affect the IL-1 $\beta$-induced phosphorylation of p38 MAP kinase, SAPK/JNK, I $\mathrm{B}, \mathrm{NF}-\kappa \mathrm{B}$ and c-Jun or the $\mathrm{I} \kappa \mathrm{B}$ level. Based on our findings, it seems unlikely that dexmedetomidine suppresses the IL- $1 \beta$-induced release of IL- 6 at the point between IL-1 $\beta$ receptors and transcription factors in C6 cells. Further studies are required to clarify the exact mechanisms underlying the inhibitory effects of dexmedetomidine on IL-6 synthesis.

In a previous study, the blood peak concentration of dexmedetomidine in human subjects after the initiation of $3-6 \mu \mathrm{g} / \mathrm{kg} / \mathrm{h}$ intravenous infusion was approximately $4-6 \mathrm{ng} / \mathrm{ml}$ (27). The neuroprotective effects of dexmedetomidine against transient focal cerebral ischemia have also been observed at $4 \mathrm{ng} / \mathrm{ml}$ $(0.02 \mu \mathrm{M})$ in rabbits $(1,3)$. In the present study, the suppressive effects of dexmedetomidine on IL-6 expression were observed at the dose of $3 \mu \mathrm{M}$, which is higher than the concentration used in clinical practice. However, in a number of studies using cultured astocytes, dexmedetomidine has exerted its effects at higher concentrations than those used in clinical practice. For example, dexmedetomidine has been shown to induce the biphasic increase in the accumulation of glutamine (second peak is observed over $25 \mu \mathrm{M}$ ) in mouse astrocytes (28), the intracellular calcium concentration (second peak is observed over $1 \mu \mathrm{M}$ ) in mouse astrocytes (29), and to inhibit oxygenglucose deprivation-induced apoptosis at a dose of $>1 \mu \mathrm{M}$ in C6 cells (7). Therefore, it is possible that the differences observed in the effective concentration between clinical and in vitro studies are due to the differences in the experimental conditions between in vivo and in vitro experiments.

Astrocytes are considered to be the main source of IL-6 in the CNS (10). IL-6 is involved in multiple physiological CNS functions, such as neuron homeostasis, astrogliosis and neuronal differentiation (10). IL-6 has also been implicated in both acute and chronic diseases of the CNS, including infection, traumatic brain injury, ischemia, multiple sclerosis, Alzheimer's disease and Parkinson's disease (10). IL-6 plays a key role in neuroinflammation, which accompanies those disorders, as both a pro-inflammatory cytokine and an antiinflammatory cytokine (10). As a pro-inflammatory cytokine, IL-6 induces astrogliosis, which is characterized by hypertrophy and the hyperplasia of astrocytes, and produces other inflammatory mediators, such as prostaglandins, cytokines, chemokines and acute phase proteins (10). On the other hand, as an anti-inflammatory cytokine, IL- 6 affects neuronal survival, proliferation, differentiation and regeneration (10). It is possible that IL-6 may be a valid therapeutic target for the treatment of disorders of the CNS $(10,30)$.

Some sedative agents used in critical care have anti-inflammatory properties (11). $\alpha_{2}$-adrenoceptor agonists interact with the immune system in a complex manner. Dexmedetomidine also suppresses immune function, but improves outcome, including mortality $(11,14,15)$. It has been reported that dexmedetomidine improves the early survival rate and suppresses plasma IL-6 levels in septic rats and that patients administered with dexmedetomodine show a decrease in serum IL-6 levels compared with midazolam or propofol administration (13-15). There are some reports that dexmedetomidine does not affect plasma IL-6 levels in patients undergoing laparoscopic cholecystectomy or spine surgery $(31,32)$. However, the effects of dexmedetomidine on cytokine synthesis, including IL-6 in the brain have not yet been fully elucidated. We previously reported that midazolam, but not propofol, inhibits the IL-1 $\beta$ induced IL-6 synthesis in C6 cells (17). The suppressive effects of midazolam were greater than those of dexmedetomidine, which were observed in the present study. Midazolam, propofol or dexmedetomidine may have different effects on the CNS in patients with elevated IL-6 levels.

Although astrocytes play important roles in the CNS (4), the effects of dexmedetomidine on astrocytes remain to be clarified (1). Astrocytes are known to protect neurons though the uptake of glutamine and the conversion to glutamate, both neurotoxicants (4). It has been reported that dexmedetomidine increases the uptake of glutamine in rat hippocampal slices or cultured mouse astrocytes $(5,28)$. Astrocytes protect neurons by the release of neurotrophic factors against brain ischemia, brain injury and neurodegenerative diseases (33). It has been shown that dexmedetomidine stimulates GDNF, one of the neurotrophic factors, released from rat primary cultured astrocytes through $\alpha_{2 \mathrm{~A}}$-adrenoceptor and the stimulation of GDNF by dexmedetomidine decreases neuronal cell death induced by oxygen-glucose deprivation (6). In C6 cells, it has been reported that dexmedetomidine inhibits the decrease in cell viability induced by HIF-1 $\alpha$ and VEGF expression under conditions of oxygen-glucose deprivation (7). Taken together with our results, it is possible that astrocytes may be an important target of dexmedetomidine. However, the effects of dexmedetomidine on the CNS and the exact mechanisms involved are not yet fully understood. Further investigations into the effects of dexmedetomidine on astrocytes are required.

In conclusion, our findings strongly suggest that dexmedetomidine inhibits the IL- $1 \beta$-induced IL- 6 synthesis independently of the adenylyl cyclase-cAMP pathway through $\alpha_{2}$-adrenoceptors in C6 glioma cells. It is possible that dexme- 
detomidine may affect the immune system in the CNS by regulating the production of IL-6.

\section{Acknowledgements}

We are very grateful to Yumiko Kurokawa for her skillful technical assistance. The present study was supported in part by a Grant-in-Aid for Scientific Research (23592248) from the Ministry of Education, Science, Sports and Culture of Japan.

\section{References}

1. Ma D, Rajakumaraswamy $\mathrm{N}$ and Maze M: $\alpha_{2}$-Adrenoceptor agonists: shedding light on neuroprotection? Br Med Bull 71: 77-92, 2004.

2. Zhang Y and Kimelberg HK: Neuroprotection by alpha 2 adrenergic agonists in cerebral ischemia. Curr Neuropharmacol 3: 317-323, 2005.

3. Sanders RD and Maze M: $\alpha_{2}$-Adrenoceptor agonists. Curr Opin Invest 8: 25-33, 2007.

4. Benarroch EE: Neuron-astrocyte interactions: partnership for normal function and disease in the central nervous system. Mayo Clin Proc 80: 1326-1338, 2005.

5. Talke P and Bickler PE: Effects of dexmedetomidine on hypoxiaevoked glutamate release and glutamate receptor activity in hippocampal slices. Anesthesiology 85: 551-557, 1996.

6. Yan M, Dai H, Ding T, Dai A, Zhang F, Yu L, Chen G and Chen Z: Effects of dexmedetomodine on the release of glial cell line-derived neurotrophic factor from rat astrocyte cells. Neurochem Int 58: 549-557, 2011.

7. Zhang $\mathrm{F}$, Ding $\mathrm{T}, \mathrm{Yu} \mathrm{L}$, Zhong $\mathrm{Y}$, Dai $\mathrm{H}$ and Yan $\mathrm{M}$ : Dexmedetomidine protects against oxygen-glucose deprivationinduced injury through the I2 imidazoline receptor-PI3K/AKT pathway in rat C6 glioma cells. J Pharm Pharmacol 64: 120-127, 2012.

8. Allan SM, Tyrrell PJ and Rothwell NJ: Interleukin-1 and neuronal injury. Nat Rev Immunnol 5: 629-640, 2005.

9. Simi A, Tsakiri N, Wang P and Rothwell NJ: Interleukin-1 and inflammatory neurodegeneration. Biochem Soc Trans 35: 1122-1126, 2007.

10. Spooren A, Kolmus K, Laureys G, Clinckers R, De Keyser J, Haegeman $G$ and Gerlo S: Interleukin-6, a mental cytokine. Brain Res Rev 67: 157-183, 2011.

11. Sanders RD, Hussell T and Maze M: Sedation \& immunomodulation. Anesthesiol Clin 29: 687-706, 2011.

12. Eser O, Fidan H, Sahin O, Cosar M, Yaman M, Mollaoglu H, Songur A and Buyukbas S: The influence of dexmedtomidine on ischemic rat hippocampus. Brain Res 1218: 250-256, 2008.

13. Qiao H, Sanders RD, Ma D, Wu X and Maze M: Sedation improves early outcome in severely septic Sprague Dawley rats. Crit Care 13: R136, 2009.

14. Venn RM, Bryant A, Hall GM and Grounds RM: Effects of dexmedetomidine on adrenocortical function, and the cardiovascular, endocrine and inflammatory responses in post-operative patients needing sedation in the intensive care unit. Br J Anaesth 86: 650-656, 2001

15. Meniş D, Hekimoğlu S, Vatan İ, Yandım T, Yüksel M and Süt N: Effects of midazolam and dexmedetomidine on inflammatory responses and gastric intramucosal $\mathrm{pH}$ to sepsis, in critically ill patients. Br J Anaesth 98: 550-552, 2007.

16. Kawashima A, Harada T, Imada K, Yano T and Mizuguchi K: Eicosapentaenoic acid inhibits interleukin-6 production in interleukin-1 $\beta$-stimulated C6 glioma cells through peroxisome proliferator-activated receptor-gamma. Prostaglandins Leukot Essent Fatty Acids 79: 59-65, 2008.
17. Tanabe $\mathrm{K}$, Kozawa $\mathrm{O}$ and Iida $\mathrm{H}$ : Midazolam suppresses interleukin-1 $\beta$-induced interleukin- 6 release from rat glial cells. J Neuroinflammation 8: 68, 2011.

18. Zumwalt JW, Thunstrom BJ and Spangelo BL: Interleukin-1 $\beta$ and catecholamines synergistically stimulate interleukin-6 release from rat C6 glioma cells in vitro: a potential role for lysophosphatidylcholine. Endocrinology 140: 888-896, 1999.

19. Laemmli UK: Cleavage of structural proteins during the assembly of the head of bacteriophage T4. Nature 227: 680-685, 1970.

20. Morioka N, Sugimoto T, Tokuhara M, Dohi T and Nakata Y: Noradrenaline induces clock gene Perl mRNA expression in C6 glioma cells through $\beta_{2}$-adrenergic receptor coupled with protein kinase A-cAMP response element binding protein (PKACREB) and Src-tyrosine kinase-glycogen synthase kinase-3 $\beta$ (Src-GSK-3ß). J Pharmacol Sci 113: 234-245, 2010.

21. Aantaa R, Marjamäki A and Scheinin M: Molecular pharmacology of $\alpha 2$-adrenoceptor subtypes. Ann Med 27: 439-449, 1995.

22. Edwards LP, Brown-Bryan TA, McLean L and Ernsberger P: Pharmacological properties of the central antihypertensive agent, moxonidine. Cardiovasc Ther 30: 199-208, 2012.

23. Nishizuka Y: Studies and perspectives of protein kinase C. Science 233: 305-312, 1986.

24. Simonds WF: G protein regulation of adenylate cyclase. Trends Pharmacol Sci 20: 66-73, 1999.

25. Gallagher HC, Bacon CL, Odumeru OA, Gallagher KF, Fitzpatrick T and Regan CM: Valproate activates phosphodiesterase-mediated cAMP degradation: relevance to C6 glioma G1 phase progression. Neurotoxicol Teratol 26: 73-81, 2004.

26. Adcock IM and Caramori G: Cross-talk between pro-inflammatory transcription factors and glucocorticoids. Immunol Cell Biol 79: 376-384, 2001

27. Iirola T, Ihmsen H, Laitio R, Kentala E, Aantaa R, Kurvinen JP, Scheinin M, Schwilden H, Schüttler J and Olkkola KT: Population pharmacokinetics of dexmedetomidine during long-term sedation in intensive care patients. Br J Anaesth 108: 460-468, 2012.

28. Huang R and Hertz L: Receptor subtype and dose dependence of dexmedetomidine-induced accumulation of $\left[{ }^{14} \mathrm{C}\right]$ glutamine in astrocytes suggests glial involvement in its hypnotic-sedative and anesthetic-sparing effects. Brain Res 873: 297-301, 2000.

29. Chen Y, Zhao Z, Code WE and Hertz L: A correlation between dexmedetomidine-induced biphasic increases in free cytosolic calcium concentration and energy metabolism in astrocytes. Anesth Analg 91: 353-357, 2000.

30. Lambertsen KL, Biber K and Finsen B: Inflammatory cytokines in experimental and human stroke. J Cereb Blood Flow Metab 32: 1677-1698, 2012.

31. Bekker A, Haile M, Kline R, Didehvar S, Babu R, Martiniuk F and Urban M: The effect of intraoperative infusion of dexmedetomidine on the quality of recovery after major surgery. $\mathrm{J}$ Neurosurg Anesthesiol 25: 16-24, 2013.

32. Kang AH, Kim YS, Hong TH, Chae MS, Cho ML, Her YM and Lee J: Effects of dexmedetomidine on inflammatory responses in patients undergoing laparoscopic cholecystectomy. Acta Anaesthesiol Scand 57: 480-487, 2013.

33. Saavedra A, Baltazar G and Duarte EP: Driving GDNF expression: the green and the red traffic light. Prog Neurobiol 86: $186-215,2008$. 